\title{
FAKTOR-FAKTOR YANG BERHUBUNGAN DENGAN STATUS GIZI DI WILAYAH KERJA UPT. PUSKESMAS KERTAK HANYAR KABUPATEN BANJAR
}

\author{
Factors Related to Nutritional Status in Work Areas \\ Puskesmas Kertak Hanyar Banjar District \\ Noor Hidayah, Kasman, Mayasari \\ Fakultas Kesehatan Masyarakat UNISKA MAB Banjarmasin \\ Email: dayah_ibnu92@yahoo.co.id
}

\begin{abstract}
Nutritional status is the state of the body which is the end result of the balance between nutrients that enter the body and its utilization. Based on the results of a preliminary study conducted by researchers in March 2017 at the UPT. Kertak Hanyar Health Center obtained data from health workers on nutritional problems, one of which was under five red lines (BGM) of 35 toddlers. This study aims to determine the relationship of independent variables with dependent variables (Education, Knowledge, Work, Income, and exclusive breastfeeding) on toddlers. This type of research uses a cross sectional design, where data collection was conducted in May 2017. The population in this study were toddlers with a total of 3,541 children. The sample in this study were 98 toddlers. The technique in taking research data was obtained through questionnaires and interviews. Data from the results of this study were processed using the chi square test, if it does not fulfill the fisher test use the significance level is $5 \%$. Factors that influence toddlers' nutritional status are maternal education level ( $p$.value $=0.017$ ), level of maternal knowledge ( .value = 0.043), family income (p.value $=0.046)$, while unrelated factors are maternal employment status ( $p$. value $=0.394)$, and Exclusive breastfeeding ( $p$. value $=1,123)$. In further research, it is hoped that research will be conducted on parenting so that it can be seen a picture of parenting for children under five. It is recommended that mothers of children under five pay more attention to diet and food consumption according to the nutritional needs of each toddler. In consuming food everyday, get used to a balanced menu, namely rice complete with side dishes, vegetables and fruit. Keywords : Education, Knowledge, Employment, Family Income, Exclusive Breastfeeding
\end{abstract}

\begin{abstract}
Abstrak
Status gizi adalah keadaan tubuh yang merupakan hasil akhir dari keseimbangan antara zat gizi yang masuk ke dalam tubuh dan utilisasinya. Berdasarkan hasil studi pendahuluan yang dilakukan oleh peneliti pada bulan Maret 2017 di UPT.Puskesmas Kertak Hanyar yang diperoleh data dari petugas kesehatan masalah gizi salah satunya balita bawah garis merah (BGM) sebanyak 35 balita. Penelitian ini bertujuan untuk mengetahui hubungan variabel bebas dengan variabel terikat (Pendidikan, Pengetahuan, Pekerjaa, Pendapatan,dan Asi eksklusif) pada balita. Jenis Penelitian ini menggunakan desain cross sectional, dimana pengumpulan data dilakukan pada bulan Mei 2017. Populasi dalam penelitian ini adalah balita dengan jumlah 3.541 balita. Sampel dalam penelitian ini sebanyak 98 balita. Teknik dalam pengambilan data penelitian diperoleh melalui kuesioner dan wawancara. Data hasil penelitian ini diolah dengan menggunakan uji chi square, bila tidak memenuhi pakai uji fisher dengan derajat kemaknaan 5\%. Faktor-faktor yang mempengaruhi status gizi balita yaitu tingkat pendidikan $\mathrm{ibu}($ p.value $=0,017)$, tingkat pengetahuan ibu $($ p.value $=0,043)$, pendapatan keluarga $($ p.value $=$ 0,046), Sedangkan faktor yang tidak berhubungan yaitu status pekerjaan ibu (p.value $=0,394)$, dan ASI Eksklusif (p.value = 1,123). Pada penelitian selanjutnya diharapkan dilakukan penelitian mengenai pola asuh sehingga dapat terlihat gambaran pola asuh orang tua terhadap anak balita. Disarankan ibu balita untuk lebih memperhatikan pola makan dan asupan konsumsi makan sesuai dengan kebutuhan gizi setiap anak balita. Dalam mengkonsumsi makanan sehari-hari biasakan dengan menu seimbang, yaitu nasi lengkap dengan lauk-pauk, sayuran dan buah.
\end{abstract}

Kata Kunci : Pendidikan, Pengetahuan, Pekerjaan, Pendapatan Keluarga, ASI Eksklusif 


\section{PENDAHULUAN}

Setiap tahun lebih dari sepertiga kematian anak di dunia berkaitan dengan masalah kurang gizi, yang dapat melemahkan daya tahan tubuh terhadap penyakit. Ibu yang mengalami kekurangan gizi pada saat hamil, atau anaknya mengalami kekurangan gizi pada usia 2 tahun pertama, pertumbuhan serta perkembangan fisik dan mentalnya akan lambat (Depkes RI, 2017).

Salah satu indikator kesehatan yang dinilai pencapaiannya dalam MDGs adalah status gizi balita. Status gizi anak balita diukur berdasarkan umur, berat badan (BB) dan tinggi badan (TB). Variabel umur, BB dan TB ini disajikan dalam bentuk tiga indikator antropometri, yaitu : berat badan menurut umur $(\mathrm{BB} / \mathrm{U})$, tinggi badan menurut umur $(\mathrm{TB} / \mathrm{U})$, dan berat badan menurut tinggi badan (BB/TB). Indikator status gizi berdasarkan indeks $\mathrm{BB} / \mathrm{U}$ memberikan indikasi masalah gizi secara umum. Indikator ini tidak memberikan indikasi tentang masalah gizi yang sifatnya kronis ataupun akut karena berat badan berkorelasi positif dengan umur dan tinggi badan. Dengan kata lain, berat badan yang rendah dapat disebabkan karena pendek (masalah gizi kronis) atau sedang menderita diare atau penyakit infeksi lain (masalah gizi akut) (Depkes RI, 2017).

Faktor-faktor yang mempengaruhi status gizi menurut Wiku Adisasmito (2010) adalah karakteristik orang tua (umur, pendidikan, pekerjaan), tingkat pengetahuan, pemberian ASI Eksklusif, pemberian MP-ASI dan penyakit infeksi. Menurut Novitasari dan Puruhita (2012) dalam penelitiannya status sosial, pendapatan keluarga, pendidikan ibu, dan ASI merupakan faktor risiko kejadian gizi buruk pada balita yang dirawat di RSUP Dr. Kariadi semarang. Dalam penelitian Setiani (2013) di kelurahan "B" kota Surakarta bahwa pengetahuan ibu, pekerjaan ibu dan pemberian ASI Eksklusif mempunyai huubungan terhadap status gizi.

Data Riskesdas tahun 2013 terdapat 19,6\% balita kekurangan gizi yang terdiri dari 5,7\% balita dengan gizi buruk dan 13,9\% berstatus gizi kurang. Sebesar 4,5\% balita dengan gizi lebih. Jika dibandingkan dengan angka prevalensi nasional tahun 2007 (18,4\%) dan tahun 2010 (17,9\%), prevalensi kekurangan gizi pada balita tahun 2013 terlihat meningkat. Balita kekurangan gizi tahun 2010 terdiri dari $13,0 \%$ balita berstatus gizi kurang dan 4,9\% berstatus gizi buruk. Perubahan terutama pada prevalensi gizi buruk yaitu dari 5,4\% tahun 2007, 4,9\% pada tahun 2010, dan 5,7\% tahun 2013. Untuk mencapai sasaran MDGs tahun 2015 yaitu 15,5\% maka prevalensi gizi buruk-kurang secara nasional harus diturunkan sebesar 4.1 \% dalam periode 2013 sampai 2015 (Depkes RI, 2017).

Menurut data laporan tahunan Dinas Kesehatan Kabupaten Banjar (2016), diketahui pada Profil Kesehatan Kabupaten Banjar UPT. Puskesmas Kertak Hanyar untuk Status Gizi Buruk dan Status Gizi Kurang berada diurutan empat setelah Puskesmas Aluh-aluh, Puskesmas Beruntung Baru, dan Puskesmas Gambut. Dari hasil laporan tahunan 2016 UPT. Puskesmas Kertak Hanyar sebanyak 3.832 balita, dan dari total balita tersebut sebanyak 69 balita yang mengalami BGM (Balita Bawah Garis Merah), 1 orang balita mengalami gizi buruk, dan sebanyak 3.732 balita gizi baik terdapat pada wilayah kerja UPT. Puskesmas Kertak Hanyar. Tujuan umum dari penelitian ini adalah untuk mengetahui Faktor-Faktor yang berhubungan dengan status gizi balita di wilayah kerja UPT. Puskesmas Kertak Hanyar Kabupaten Banjar.

\section{BAHAN DAN METODE}

Jenis penelitian ini menggunakan desain "cross sectional" untuk melihat faktor-faktor yang berhubungan dengan status gizi seperti pendidikan ibu, pengetahuan ibu, pekerjaan ibu, pendapatan keluarga, dan pemberian ASI eksklusif. Populasi penelitian ini adalah ibu yang membawa balitanya ke Poli Gizi di UPT. Puskesmas Kertak Hanyar dan sebanyak 3.541 balita pada bulan Januari-Mei yang ada di wilayah kerja Puskemas Kertak Hanyar pada tahun 2017 dengan jumlah sampel 98 balita. Pengumpulan data dengan melakukan wawancara langsung dengan ibu balita menggunakan kuesioner. Data yang telah terkumpul kemudian dianalisis menggunakan program SPSS dengan uji Chi-Square. 


\section{HASIL DAN PEMBAHASAN}

\section{Analisis Univariat}

Analisis univariat menyajikan distribusi frekuensi variabel penelitian. Tabel 1 menunjukkan bahwa sebagian besar responden adalah ibu yang memiliki pendidikan terakhir Dasar (SD-SMP) sebanyak 43 responden (43,9\%). Sebanyak 57,1\% responden bekerja. Terdapat $67,3 \%$ responden dengan pendapatan keluarganya $\geq$ Rp.2.258.000,-. Untuk kategori pengetahuan, sebanyak $61,2 \%$ dengan kategori cukup. Sedangkan untuk variabel status gizi sebanyak 64,3\% kategori baik. Untuk kategori ASI Eksklusif sebagian besar tidak eksklusif yakni $67,7 \%$.

Tabel 1. Distribusi Frekuensi Responden di Wilayah Kerja UPT. Puskesmas Kertak Hanyar Kab. Banjar.

\begin{tabular}{lcc}
\hline Variabel & n & \% \\
\hline Pendidikan & & \\
Dasar (SD-SMP) & 43 & 43,9 \\
Menengah (SMA) & 39 & 39,8 \\
$\quad$ Perguruan Tinggi & 16 & 16,3 \\
Pekerjaan & & \\
$\quad$ Tidak Bekerja & 42 & 42,9 \\
$\quad$ Bekerja & 56 & 57,1 \\
Pendapatan & & \\
$\quad$ < Rp. 2.258.000 & 32 & 32,7 \\
$\quad$ Rp. 2.258.000 & 66 & 67,3 \\
\hline Pengetahuan & & \\
Kurang & 10 & 10,2 \\
$\quad$ Cukup & 60 & 61,2 \\
$\quad$ Baik & 16 & 16,3 \\
\hline Status Gizi & & \\
$\quad$ Gizi Buruk & 6 & 6,1 \\
$\quad$ Gizi Kurang & 29 & 29,6 \\
$\quad$ Gizi Baik & 63 & 64,3 \\
\hline ASI Eksklusif & & \\
$\quad$ Tidak Eksklusif & 66 & 67,7 \\
$\quad$ Eksklusif & 32 & 32,7 \\
\hline Jumlah & $\mathbf{9 8}$ & $\mathbf{1 0 0}$ \\
\hline
\end{tabular}

\section{Analisis Bivariat}

Analisa bivariat dilakukan untuk melihat adanya hubungan antara faktor-faktor yang diduga berhubungan seperti (pendidikan ibu, pengetahuan ibu, pekerjaan ibu, pendapatan keluarga, dan ASI Eksklusif) dengan status gizi balita di wilayah kerja UPT. Puskesmas Kertak Hanyar Kabupaten Banjar.
Hasil analisis bivariat dapat dilihat pada tabel 2 sebagai berikut.

\section{Hubungan Pendidikan dengan Status Gizi pada Balita}

Tabel 2 menunjukkan proporsi responden dengan status gizi kurang dan buruk lebih banyak pada ibu yang berpendidikan dasar $51,6 \%$ dibanding ibu yang berpendidikan menengah $(25,6 \%)$ dan perguruan tinggi $(18,8 \%)$. Sedangkan balita dengan status gizi baik lebih banyak pada ibu yang berpendidikan perguruan tinggi $(81,3 \%)$. Hasil uji statistik didapat data p.value 0,017 artinya ada hubungan bermakna antara pendidikan dengan status gizi.

Pendidikan yang baik yang dimiliki ibu menjadi salah satu faktor penentuan status gizi pada anak balita. Semakin tinggi pendidikan yang dimiliki ibu semakin besar peluang untuk memberikan makanan yang cukup gizi dan pemenuhan gizi yang sesuai dan optimal bagi balita. Pendidikan yang baik yang dimiliki ibu akan berpengaruh pula pada pendidikan gizi yang dimilikinya sehingga lebih mampu menentukan makanan yang sesuai untuk pemenuhan tumbuh kembang bagi balita dan menjadi salah satu upaya untuk bisa menanggulangi masalah gizi.

Penelitian ini juga sesuai dengan teori Suhardjo dkk (2003) yang menyatakan tingkat pendidikan turut menentukan mudah tidaknya seseorang menyerap dan memahami pengetahuan gizi dan kesehatan. Selain itu pendidikan orang tua merupakan salah satu faktor penting dalam tumbuh kembang anak, karena dengan pendidikan yang baik maka orang tua dapat menerima segala informasi tentang cara pengasuhan anak yang baik, cara menjaga kesehatan anak, dan pendidikannya.

Rendahnya pengetahuan dan pendidikan orang tua khususnya ibu merupakan faktor penyebab mendasar terpenting karena sangat mempengaruhi kemampuan individu, keluarga dan masyarakat dalam mengelola sumber daya yang ada untuk mendapatkan kecukupan bahan makanan serta sejauh mana sarana pelayanan kesehatan, gizi dan sanitasi lingkungan yang tersedia dimanfaatkan 
dengan sebaik-baiknya (Depkes RI, 2000). Selanjutnya rendahnya tingkat pendidikan dapat menyebabkan rendahnya pemahaman terhadap apa yang dibutuhkan pada pengasuhan perkembangan optimal anak.

Hasil ini sejalan dengan penelitian Khayati (2010), analisis bivariat di peroleh p.value sebesar 0,030, maka p.value lebih kecil sehingga menunjukkan ada hubungan antara tingkat pendidikan ibu dengan status gizi balita pada keluarga buruh tani di Desa Situwangi Kecamatan Rakit Kabupaten Banjarnegara tahun 2010. Pendidikan merupakan landasan untuk meningkatkan kesejahteraan, kemajuan, dan kemakmuran. Pendidikan ibu merupakan faktor luar yang turut andil dalam menentukan status gizi balita. Tinggi rendahnya tingkat pendidikan ibu erat kaitannya dengan tingkat pengetahuan gizi dalam menyerap dan memahami pengetahuan gizi. Pendidikan gizi merupakan salah satu upaya penanggulangan masalah gizi. Faktor penyebab masalah gizi adalah kurangnya ketersediaan pangan, rendahnya daya beli, dan rendahnya pendidikan atau pengetahuan yang dipengaruhi sosial budaya dalam (Khayati, 2010). Tingkat pendidikan merupakan salah satu faktor yang menentukan mudah tidaknya seseorang menyerap dan memahami pengetahuan gizi yang mereka peroleh. Sebab tingkat pendidikan ibu berpengaruh terhadap kualitas dan kuantitas makanan yang diberikan kepada balitanya.

\section{Hubungan Pengetahuan dengan Status Gizi pada Balita}

Tabel 2 menunjukkan proporsi responden dengan status gizi kurang dan buruk lebih banyak pada ibu yang bepengetahuan cukup $(45,0 \%)$ dibanding ibu yang berpengetahuan kurang $(30,0 \%)$ dan Ibu yang bepengetahuan baik (17,0\%). Sedangkan balita dengan status gizi baik lebih banyak pada ibu yang berpengetahuan baik (82,1\%) dibanding ibu yang bepengetahuan kurang. Hasil uji statistik didapat data p.value 0,043 artinya ada hubungan bermakna antara pengetahuan dengan status gizi. Rendahnya pengetahuan tentang gizi pada ibu akan berpengaruh pada pemberian makanan yang sesuai pemenuhan zat gizi pada tumbuh kembang balita. Karena kebutuhan dan kecukupan gizi balita tergantung dari konsumsi makanan yang diberikan oleh ibu atau pola pengasuhan anak. Seorang ibu akan berusaha untuk memenuhi kebutuhan gizi setiap anggota keluarga sesuai dengan pengetahuan yang dimilikinya.

Hasil penelitian ini sesuai dengan teori Sediaoetama (2008) bahwa semakin tinggi pengetahuan ibu tentang gizi dan kesehatan maka penilaian terhadap makanan semakin baik, artinya penilaian terhadap makanan tidak terpancang terhadap rasa saja, tetapi juga memperhatikan hal-hal yang lebih luas. Pengetahuan tentang gizi memungkinkan seseorang memilih dan mempertahankan pola makan berdasarkan prinsip ilmu gizi. Pada keluarga dengan tingkat pengetahuan yang rendah seringkali anak harus puas dengan makan seadanya yang tidak memenuhi kebutuhan gizi. Pengetahuan gizi yang diperoleh ibu sangat bermanfaat bagi balita apabila ibu berhasil mengaplikasikan pengetahuan gizi yang dimilikinya (Yayuk Farida, 2004 dalam Khayati, 2010).

Selain teori diatas hasil penelitian oleh Khayati (2010) yang menyatakan ada hubungan antara tingkat pengetahuan ibu dengan status gizi balita pada keluarga buruh tani di desa Situwangi Kecamatan Rakit Kabupaten Banjarnegara tahun 2010. Pengetahuan tentang gizi bisa didapat dengan selalu mengikuti penuyuluhan tentang gizi dan kesehatan yang selalu diberikan petugas kesehatan baik di puskesmas atau pun di posyandu-posyandu.

\section{Hubungan Pekerjaan dengan Status Gizi pada Balita}

Tabel 2 menunjukkan proporsi responden dengan status gizi kurang dan buruk lebih banyak pada ibu yang tidak bekerja $(40,5 \%)$ dibanding dengan ibu yang bekerja (32,1\%). Sedangkan balita dengan status gizi baik lebih banyak pada ibu yang berkerja $(67,9 \%)$ dibandingkan ibu yang tidak bekerja $(59,5 \%)$. Hasil uji statistik didapat p.value 0,394 artinya tidak ada hubungan bermakna antara pekerjaan dengan status gizi.

Ibu yang bekerja diluar rumah pasti akan sulit memantau dan memberikan makanan yang baik yang 
Tabel 2. Faktor-Faktor yang Berhubungan dengan Status Gizi di Wilayah Kerja UPT. Puskesmas Kertak Hanyar Kabupaten Banjar

\begin{tabular}{|c|c|c|c|c|c|c|c|}
\hline \multirow{3}{*}{ Variabel } & \multicolumn{4}{|c|}{$\begin{aligned} \text { Status Gizi } \\
\end{aligned}$} & \multirow{2}{*}{\multicolumn{2}{|c|}{ Jumlah }} & \multirow{3}{*}{ p.value } \\
\hline & \multicolumn{2}{|c|}{$\begin{array}{c}\text { Gizi Kurang + } \\
\text { Gizi Buruk }\end{array}$} & \multicolumn{2}{|c|}{ Gizi Baik } & & & \\
\hline & $\mathrm{n}$ & $\%$ & $\mathrm{n}$ & $\%$ & $\mathrm{~N}$ & $\%$ & \\
\hline \multicolumn{8}{|l|}{ Pendidikan } \\
\hline Dasar (SD-SMP) & 22 & 51,6 & 21 & 48,8 & 43 & 100 & \multirow{3}{*}{0,017} \\
\hline Menengah (SLTA/SMA) & 10 & 25,6 & 29 & 74,4 & 39 & 100 & \\
\hline Perguruan Tinggi & 3 & 18,8 & 13 & 81,3 & 16 & 100 & \\
\hline \multicolumn{8}{|l|}{ Pengetahuan } \\
\hline Kurang & 3 & 30 & 7 & 70 & 10 & 100 & \multirow[t]{3}{*}{0,043} \\
\hline Cukup & 27 & 45 & 33 & 55 & 60 & 100 & \\
\hline Baik & 5 & 17 & 23 & 82,1 & 28 & 100 & \\
\hline \multicolumn{8}{|l|}{ Pekerjaan } \\
\hline Tidak Bekerja & 17 & 40,5 & 25 & 59,5 & 42 & 100 & \multirow{2}{*}{0,394} \\
\hline Bekerja & 18 & 32,1 & 38 & 67,9 & 56 & 100 & \\
\hline \multicolumn{8}{|l|}{ Pendapatan } \\
\hline < Rp. 2.258.000 & 7 & 21,9 & 25 & 78,1 & 32 & 100 & \multirow[t]{2}{*}{0,046} \\
\hline$\geq$ Rp. 2.258 .000 & 28 & 42,4 & 38 & 57,6 & 66 & 100 & \\
\hline \multicolumn{8}{|l|}{ Asi Eksklusif } \\
\hline Tidak Eksklusif & 27 & 40,9 & 39 & 59,1 & 66 & 100 & \multirow[t]{2}{*}{0,123} \\
\hline Eksklusif & 8 & 25 & 24 & 75 & 32 & 100 & \\
\hline
\end{tabular}

sesuai gizi untuk perkembangan dan pertumbuhan balita. Dibandingkan ibu yang tidak bekerja mempunyai peluang lebih banyak untuk memberikan makanan yang lebih baik yang sesuai gizi balita. Dari hasil kuesioner diketahui jumlah anggota keluarga respoden sebagian besar berjumlah antara 5 (lima) sampai dengan 8 (delapan) orang tentunya hal ini juga berpengaruh pada pembelian kebutuhan makanan yang mencukupi zat gizi keluarga. Semakin banyak jumlah anggota keluarga semakin terbagi konsumsi pada setiap anggota keluarga tentunya akan mempengaruhi kebutuhan zat gizi setiap anggota keluarga ada yang terpenuhi dan ada yang tidak mencukupi zat gizi yang mereka konsumsi. Ternyata hal ini tidak berhubungan karena ibu yang bekerja mempunyai tingkat pendidikan yang berbeda dan tingkat pendidikan yang lebih tinggi serta memiliki tingkat sosial yang lebih baik. Dengan tingkat pendidikan ibu yang lebih tinggi juga berpengaruh pada pengetahuan yang lebih baik maka akan mempengaruhi sikap ibu dalam pola pemberian makanan terhadap anak balita yang baik. Pada ibu yang bekerja tentu memiliki waktu yang lebih sedikit yang diberikan kepada anak balitanya, tetapi ibu yang bekerja dapat membelanjakan makanan atau bahan makanan yang kualitas gizinya lebih baik untuk balita dengan bertambahnya pendapatan keluarga.

Hal ini sejalan dengan penelitian dengan penelitian Ucu Suhendri (2009) bahwa dari hasil uji statistik yang dilakukan diperoleh p.value 0,620 yang menunjukkan bahwa tidak ada hubungan pekerjaan dengan status gizi pada balita. Hasil ini menunjukkan bahwa sebagian ibu memiliki waktu yang yang lebih banyak untuk mengasuh dan merawat anaknya karena ibu tidak bekerja diluar rumah untuk mancari nafkah. Namun hal ini tidak diimbangi dengan pemberian makanan yang seimbang dan bergizi pada anak balitanya. Sebab tanpa diberi jaminan makanan yang bergizi dan pola asuh yang benar, maka anak akan mengalami kekurangan gizi.

Hasil penelitian ini tidak jauh berbeda dengan hasil penelitian Miko (2003) bahwa proporsi gizi kurang pada anak umur 6-60 bulan mempunyai ibu tidak bekerja lebih banyak (22,4\%) dibandingkan dengan anak yang mempunyai ibu bekerja $(19,9 \%)$ di Kecamatan Bojongasih Kabupaten Tasikmalaya.

Hubungan Pendapatan dengan Status Gizi pada Balita 
Tabel 2 menunjukkan proporsi responden dengan status gizi kurang dan buruk lebih banyak pada keluarga yang memiliki penghasilan < Rp. 2.258.000,- sebesar $(78,1 \%)$ dibanding dengan keluarga yang status gizinya baik yang berpenghasilan $\geq$ Rp. 2.258.000,- sebanyak (57,6\%) . Hasil uji statistik didapat data p.value 0,046 artinya ada hubungan bermakna antara pendapatan keluarga dengan status gizi. Pendapatan yang tinggi pada keluarga adalah pengaruh besar dalam pemenuhan zat gizi pada keluarga terutama pada balita dalam sehari-harinya. Pendapatan yang tinggi yang dimiliki mempengaruhi daya beli pada makanan yang akan dikonsumsi yang memenuhi dan sesuai zat gizi. Pendapatan rendah biasanya tidak lagi memperhatikan makanan yang dikonsumsi dengan mempertimbangkan nilai gizi, tetapi nilai materi lebih menjadi pertimbangan. Akan tetapi tidak menutup kemungkinan bahwa keluarga yang berpenghasilan rendah dapat mengkonsumsi makanan yang mempunyai nilai gizi yang baik.

Hasil penelitian ini sesuai dengan teori Supariasa (2001) menyebutkan bahwa pendapatan keluarga mempengaruhi pola makan, proporsi anak yang mengalami gizi kurang berbanding terbalik dengan pendapatan keluarga, semakin kecil pendapatan penduduk semakin tinggi prosentase anak yang kekurangan gizi. Sebab utama gizi kurang pada anak balita adalah rendahnya penghasilan keluarga. Pada umumnya jika pendapatan naik jumlah dan jenis makanan cenderung juga membaik.

Hasil ini sejalan dengan penelitian Khayati (2010) hasil uji bivariat di peroleh p.value sebesar 0,008 maka p. value lebih kecil dari 0,05 $(0,008<0,05)$, sehingga menunjukkan ada hubungan antara pendapatan keluarga dengan status gizi balita pada keluarga buruh tani di Desa Situwangi Kecamatan Rakit Kabupaten Banjarnegara tahun 2010. Pendapatan seseorang identik dengan mutu sumber daya manusia, sehingga seseorang yang berpendidikan tinggi umumnya memiliki pendapatan yang relatif tinggi pula. Pendapatan keluarga juga tergantung pada jenis pekerjaan suami dan anggota keluarga lainnya. Pendapatan keluarga akan relatif lebih besar jika suami dan istri bekerja diluar rumah.

\section{Hubungan Asi Eksklusif dengan Status Gizi pada Balita}

Tabel 2 menunjukkan proporsi responden dengan status gizi kurang dan buruk lebih banyak pada ibu yang tidak memberikan ASI eksklusif $(40,9 \%)$ dibanding ibu yang memberikan ASI secara eksklusif (25,0\%). Sedangkan balita dengan status gizi baik lebih banyak pada ibu yang memberikan ASI eksklusif $(75,0 \%)$ dibanding pada ibu yang tidak memberikan ASI eksklusif (59,1\%). Hasil uji statistik didapat data p.value $(0,123)$ artinya tidak ada hubungan bermakna antara ASI eksklusif dengan status gizi.

Pada penelitian ini ibu yang tidak memberikan ASI eksklusif memiliki anak dengan gizi kurang dan gizi buruk lebih banyak dari pada ibu yang memberikan ASI Eksklusif. Sedangkan ibu yang tidak memberikan ASI Eksklusif pada anak balita dengan status gizi baik lebih banyak dari pada ibu yang memberikan ASI Eksklusif. Hal ini bukan berarti dengan tidak memberikan ASI Eksklusif lebih baik dari ibu yang memberikan ASI Eksklusif walaupun keduanya sama dalam pertumbuhan dan perkembangannya, akan tetapi bayi balita yang diberikan ASI Eksklusif memiliki risiko sakit lebih rendah karena sistem imun yang lebih baik.

Penelitian ini bertolak belakang dengan teori yang menyebutkan bahwa pemberian ASI dapat mencegah malnutrisi pada anak. Teori ini menyebutkan bahwa terdapat korelasi positif antara pemberian ASI dengan status gizi anak. Semakin sering anak yang mendapat perhatian (lewat menyusui) mempunyai probabilitas yang lebih baik dibandingkan dengan bayi yang tidak disusui atau disusui tapi hanya sebentar saja (Nasution, 2006 dalam Ramadhani, 2015). Karena adanya pertambahan umur bayi yang disertai kenaikan berat badan maupun tinggi badan, maka kebutuhan akan energi maupun nutrient akan bertambah pula (Adriani, dkk, 2012).

Penelitian ini berbeda dari penelitian yang dilakukan oleh Setiani (2013) yang hasil uji statistik penelitiannya diperoleh bahwa ada hubungan pemberian ASI eksklusif dengan status gizi bayi usia 
6-12 bulan di Posyandu Kelurahan "B" Kota Surakarta. Hal ini sesuai dengan teori bahwa rendahnya proporsi bayi terutama sampai usia 6 bulan yang mendapatkan ASI eksklusif berpengaruh terhadap status gizi bayi. (Bappenas, 2008, dalam Setiani, 2013). Dalam penelitian ini didapatkan hasil bahwa ibu-ibu di Posyandu Kelurahan "B" Kota Surakarta yang tidak memberikan ASI Eksklusif mempunyai bayi dengan status gizi tidak baik lebih besar dari pada ibu yang memberikan ASI eksklusif.

ASI merupakan makanan bayi yang terbaik untuk memenuhi seluruh kebutuhan zat gizi yang diperlukan untuk pertumbuhan dan perkembangan dan kesehatan bayi 0 bulan sampai usia 6 bulan. Menurut Nuryanto (2002) bahwa status pekerjaan ibu tidak berpengaruh terhadap pemberian ASI Eksklusif dan hanya mempunyai resiko 1,16 kali untuk menghentikan pemberian ASI dibandingkan ibu yang tidak bekerja. Hal ini juga diperkuat dengan adanya peraturan pemerintah tentang pemberian ASI pada ibu yang bekerja. UU Ketenagakerjaan Tahun 2003 Pasal 83 menyatakan bahwa pekerja/buruh perempuan yang anaknya masih menyusui harus diberi kesempatan sepatutnya untuk menyusui anaknya jika hal itu harus dilakukan selama waktu kerja.

Peraturan bersama tiga menteri: Menteri Negara Pemberdayaan Perempuan, Menteri Tenaga Kerja dan Transmigrasi, dan Menteri Kesehatan Nomor 48/MEN.PP/XII/2008, 27/MEN/XII/2008, DAN 1177/MENKES/PB/XII/2008 Tahun 2008 Tentang Peningkatan Pemberian Air Susu Ibu Selama Waktu Kerja di Tempat Bekerja. Tujuan peraturan bersama ini adalah untuk memberi hak ibu menyusui yang berupa kesempatan dan fasilitas kepada ibu bekerja untuk memberikan/memerah ASI selama waktu kerja dan menyimpan ASI perah tersebut.

\section{KESIMPULAN}

Berdasarkan hasil penelitian didapatkan bahwa ada hubungan tingkat pendidikan, pengetahuan dan pendapatan keluarga dengan status gizi pada balita di wilayah kerja UPT. Puskesmas Kertak Hanyar Kabupaten Banjar. Tidak adanya hubungan pekerjaan dan pemberian ASI secara eksklusif dengan status gizi pada balita di wilayah kerja UPT. Puskesmas Kertak Hanyar Kabupaten Banjar. Kepada pihak Puskesmas perlu meningkatkan kegiatan monitoring dan penilaian status gizi secara berkala yang dilaksanakan dalam Pos Gizi dan Klinik Gizi, dan memberikan bimbingan konsultasi gizi terhadap ibu balita yang dilakukan secara rutin $( \pm 1 x$ perbulan). Mengingat bahwa anak balita sangat membutuhkan asupan kecukupan gizi untuk pertumbuhan dan perkembangan yang lebih baik.

\section{DAFTAR PUSTAKA}

Adisasmito, Wiku. 2010. Sistem Kesehatan. Jakarta: PT Raja Grafindo Persada.

Adriani dan Wirjatmadi. 2012. Peranan Gizi dalam Siklus Kehidupan. Kencana. Jakarta.

Depkes RI, 2000. Rencana aksi pangan dan gizi nasional. Depkes RI, Jakarta.

Depkes RI, 2017. Pedoman Strategi KIE Keluarga Sadar Gizi (KADARZI). Jakarta: Direktorat Bina Gizi Masyarakat.

Dinas Kesehatan Kabupaten Banjar, 2017. Laporan Profil Tahun 2016.

Khayati, Sri., 2010. Faktor Yang Berhubungan Dengan Status Gizi Balita Pada Keluarga Buruh Tani Di Desa Situwangi Kecamatan Rakit Kabupaten Banjarnegara Tahun 2010. Skripsi. Jurusan Ilmu Kesehatan Masyarakat Fakultas Ilmu Keolahragaan, Universitas Negeri Semarang. [Online]. lib.unnes.ac.id/6629/1/8075_A.pdf.

Miko, Hadiyat., 2003. Faktor-Faktor Yang Berhubungan Dengan Status Gizi (KEP) Anak umur 6-60 bulan di Kecamatan Bojongasih Kabupaten Tasikmalaya Tahun 2002. Depok: Tesis FKM UI.

Nuryanto, 2002. Hubungan antara pekerjaan ibu dengan kelangsungan pemberian ASI saja pada anak usia 011 bulan. Tesis, Fakultas Kesehatan Masyarakat Universitas Indonesia.

Novitasari A, Dewi dan Puruhita, Niken., 2012. FaktorFaktor Risiko Kejadian Gizi Buruk Pada Balita Yang Dirwat Di RSUP Dr.Kariadi Semarang. Jurnal Kedokteran Diponegoro. Vol. 1, No. 1. [Online]. https:/ / ejournal3.undip.ac.id/index.php/med ico/article/view/1587.

Ramadhani, Rizka Lailia., 2015. Hubungan Riwayat ASI Eksklusif Dengan Status Gizi Balita Usia 7-36 Bulan Di Wilayah Puskesmas Gondokusuman 1 Tahun 2015. Naskah Publikasi.[Online]. digilib.unisayogya.ac.id/.../1/RIZKA\%20LAI LIA \%20RAMADHANI_201410104305...Progra 
m Studi Bidan Pendidik Jenjang DIV, Sekolah Tinggi Ilmu Kesehatan "AISYIYAH" Yogyakarta.

Sediaoetama, Achmad Djaeni., 2008,. Ilmu Gizi : untuk Mahasiswa dan Profesi Jilid I. Jakarta : Dian Rakyat.

Setiani, Ditya Yankusuma., 2013. Faktor-Faktor Yang Berhubungan Dengan Status Gizi Bayi Usia 6-12 Bulan Di Posyandu Kelurahan "B" Kota Surakarta. [Online].ejournal.stiksintcarolus.ac.id/file.php ?...ARTIKEL\%20ILMIAH\%20DITYA...Progra m Studi S1 Keperawatan, STIK SINT Carolus, Jakarta.
Suhardjo, dkk, 2003, Pangan Gizi dan Pertanian, Jakarta: UI Press

Suhendri, Ucu. 2009. Faktor-Faktor Yang Berhubungan Dengan Status Gizi Anak Dibawah Lima Tahun (Balita) di Puskesmas Sepatan Kecamatan Sepatan Kabupaten Tangerang Tahun 2009. Skripsi. Fakultas Kedokteran dan Ilmu Kesehatan UIN Syarif Hidayatullah : Jakarta.

Supariasa, I Dewa Nyoman., Bachyar Bakri dan Ibnu Fajar., 2001. Penilaian Status Gizi. Jakarta : Buku Kedokteran EGC. 